\title{
A complexidade de lidar com pessoas
}

MARIA JOSÉ RIBAS*

"A dificuldade em lidar com a complexidade resulta da dificuldade de compreender a simplicidade" Agostinho da Silva

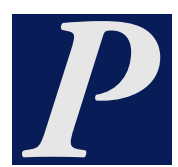

rocuramos instintivamente $o$ linear, o simples, o lógico, o seguro, o previsivel, o óbvio. Mas o complexo, o caos, a desordem e o imprevisto impregnam a natureza, as relações, a vida, a prática clínica.

O exercício da medicina envolve encontros com seres humanos. Humanos que não figuram nos livros de texto. São ricos em capacidades como a auto-consciência, a personalidade, a criatividade, a imitação e a manipulação, que lhes dão a habilidade de se realizarem ou de se autodestruírem.

A falência em apercebermo-nos desta complexidade pode resultar no nosso próprio insucesso como médicos ou num "sucesso" que consiste na resolução dos problemas errados e, logo, numa falsa sensação de dever cumprido.

A doença pode ser abordada através de algoritmos simplificadores mas o doente não: muitas situações são imprevisiveis, alguns problemas não são resolúveis e algumas incertezas são inevitáveis. A complexidade não é um conceito teórico e sim um facto da vida. Tudo está ligado a tudo, como escreve Humberto Maritotti. E é com base nesta, talvez, única certeza, que pensamos e construímos o dossier deste número da Revista Portuguesa de Clínica Geral.

"Superficial complexity arises from deep simplicity." Murray Gell-Mann
O primeiro artigo, de Mariana Tudela, Filipa Almada Lobo e Vitor Ramos, fala-nos dos desafios propostos pela complexidade na medicina geral e familiar. O médico de familia trabalha com pessoas, famílias e com todo o tipo de problemas biomédicos, psicossociais e relacionais, pelo que deve ser capaz de aceitar a natureza contraditória da condição humana e das relações sociais e a influência destas nos processos de saúde-doença.

A cultura médica ainda dominante tem-se mostrado insuficiente para explicar e resolver os problemas, frequentemente múltiplos e não estritamente clínicos, que constituem a nossa prática. Sem esquecer que a nossa capacidade de compreensão tem limites, os autores desafiam-nos a tomar as nossas decisões, e a modificá-las, se necessário.

Humberto Mariotti relembra-nos que cada observador percebe o mundo externo de acordo com a sua estrutura cognitiva, isto é, do modo como está preparado para percebê-lo. No caso da medicina, as acções de saúde não são "objectivas" e unidireccionais, do tipo médico-paciente. Ao contrário, elas são uma via de mão dupla entre o sujeito, o observador, o observado, o médico e o paciente. $\mathrm{O}$ autor conclui afirmando que a atitude de cada um em relação à doença varia na razão directa da complexidade da condição humana e das suas contingências.

No terceiro artigo, Jorge Brandão afirma que os grupos Balint, sendo eles próprios sistemas de apoio ao modo de lidar melhor e mais eficientemente com a complexidade da relação médico-doente, podem integrar-se na nossa 


\section{EDITORIAL}

prática, pois potenciam a diversidade $\mathrm{e}$ impulsionam as mudanças. Os grupos Balint devem ser vistos como instrumentos de aprendizagem contínua que têm como objecto de trabalho as dificuldades surgidas na relação médico-doente, e são, também, protectores desta mesma relação.

João Guerra debruça-se sobre a organização da prestação de cuidados aos doentes com doenças crónicas. Baseando-se num caso clínico que ilustra bem as dificuldades que um doente crónico enfrenta no seu relacionamento com os serviços para satisfazer as suas necessidades multidimensionais, o autor defende que uma integração de cuidados bem planeada se traduz em múltiplos benefícios, como a promoção de parcerias, a eliminação de duplicação de procedimentos, a maximização da utiliza- ção de recursos, a optimização da coordenação intersectorial e a capacitação para a partilha de dados e uma melhor prática clínica.

Por último, Luís Lapão afirma que uma relação produtiva ocorre quando as interacções entre as partes de um sistema complexo produzem novas, valiosas e imprevisíveis competências que não estavam presentes em nenhuma das partes. A compreensão dos fenómenos da complexidade pode ajudar a aumentar a participação do cidadão na saúde, responsabilizando-o e atribuindo-lhe um papel mais activo na gestão da sua saúde. Conclui afirmando que o futuro da medicina passa por um reforço da importância da medicina familiar, tirando vantagem da sua forte ligação aos cidadãos, cujo envolvimento deve ser potenciado. 